強制炭酸化したセメント硬化体の加熱に伴う変化

庄司慎 ${ }^{* 1}$ 盛岡実 ${ }^{*}$ 横関康祐 ${ }^{* 3}$ 今本啓一 ${ }^{* 4}$

*1 デンカ株式会社 インフラ・ソーシャルソリューション部門特殊混和材部技術課 ( 日本橋室町 2-1-1)

*2 デンカ株式会社 青海工場セメント・特混研究部 (テ949-0393 新潟県糸魚川市青海 2209)

*3 鹿島建設株式会社 技術研究所 ( ⿳182-0063 東京都調布市飛田給 2-19-1)

*4 東京理科大学 工学部第二部建築学科 ( $125-8585$ 東京都葛飾区新宿 6-3-1)

\begin{abstract}
要旨：セメントペーストを強制的に炭酸化し、加熱に伴う変化を検討した。封緘養生したセメントペース 卜は $400{ }^{\circ} \mathrm{C}$ 以上に加熱すると水酸化カルシウムが分解し、0.1 $\mu \mathrm{m}$ 程度の空隙が増加した。一方、强制炭 酸化養生を施したセメントペーストは $600{ }^{\circ} \mathrm{C}$ ま妿熱しても相組成の変化や空隙構造に大きな変化は見 られなかった。 $700{ }^{\circ} \mathrm{C} に$ 加熱すると、0.01 $\mu \mathrm{m}$ 程度の空隙が増加した。また、水硬性にそしく炭酸化に活 性が高い $\gamma-\mathrm{C}_{2} \mathrm{~S}$ を結合材の一部として使用したところ、加熱後の空隙量は減少した。
\end{abstract}

キーワード：耐火、炭酸化、水酸化カルシウム、炭酸カルシウム、ペースト

1. はじめに

コンクリートは建設省告示第 1400 号において不燃材 料として分類されているが、火災の熱に曝されると爆 裂を生じる恐れがある1-6)。これはコンクリート内の自 由水や水和物の結合水が急激な加熱を受けて水蒸気と なり、内圧が急上昇して空隙を破壞し、連鎖的に爆裂 が発生する説が有力である ${ }^{2,6)}$ 。そこで有機繊維を混入 し、水蒸気圧を逃す連結パスをつくったり、コンクリー 卜表面に耐火被覆材を施して、コンクリートの急激な温 度上昇を制御する方法が提案されている $1,5,6)$ 。爆裂のほ かにも高温の熱履歴を受けたコンクリートは圧縮強度 も低下することが知られている年年。この原因としては 水和物の分解が挙げられる。Fig. 1 に示すようにセメン トの水和物であるエトリンガイトは $100{ }^{\circ} \mathrm{C}$ 程度までに、 C-S-H は $400{ }^{\circ} \mathrm{C}$ 程度までに、水酸化カルシウムは 400 $\sim 500{ }^{\circ} \mathrm{C}$ 程度で分解する。一般的に普通コンクリート は $300{ }^{\circ} \mathrm{C}$ 程度まで、高強度コンクリートは $200{ }^{\circ} \mathrm{C}$ 程度 までの火害であれば深刻な事態とはならないとされてい $3^{7-8)}$ 。

一方で JASS5 では、火熱を受けた時の部材の耐力が 著しく低下することがないよう、内部の鉄筋の温度が一 定限度以上に上昇しないという条件を定めるべきとし て抢り、この温度は、柱拧よび梁では鉄筋の降伏点が 常温時の抢よそ $1 / 2$ になる $500{ }^{\circ} \mathrm{C}$ (床・屋根・壁では $\left.550{ }^{\circ} \mathrm{C}\right)$ とされている ${ }^{8)}$ 。

これらのことから、コンクリートも $600{ }^{\circ} \mathrm{C}$ 程度まで の加熱に耐えられれば、鉄筋コンクリート構造物として

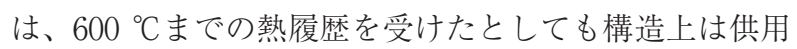
が継続できるものと考えられる。

そこで本研究では炭酸化コンクリートに着目した。炭

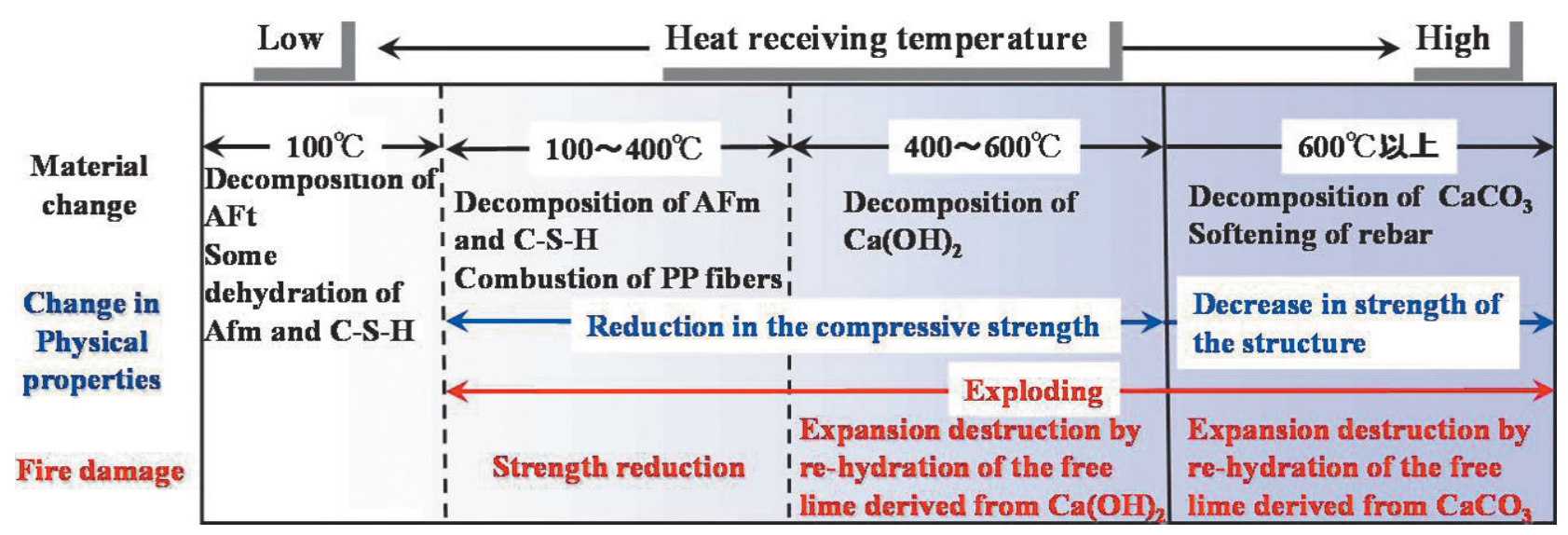

Fig. 1 Change of the heat-receiving and properties 
Table 1 Employed material

\begin{tabular}{|c|c|}
\hline Material & Details \\
\hline Water $(\mathrm{W})$ & Tap water \\
\hline Cement $(\mathrm{C})$ & Ordinary Portland Cement $(\mathrm{OPC})$ \\
\hline Carbonation admixture & ${\mathrm{\gamma}-\mathrm{C}_{2} \mathrm{~S}}$ \\
\hline
\end{tabular}

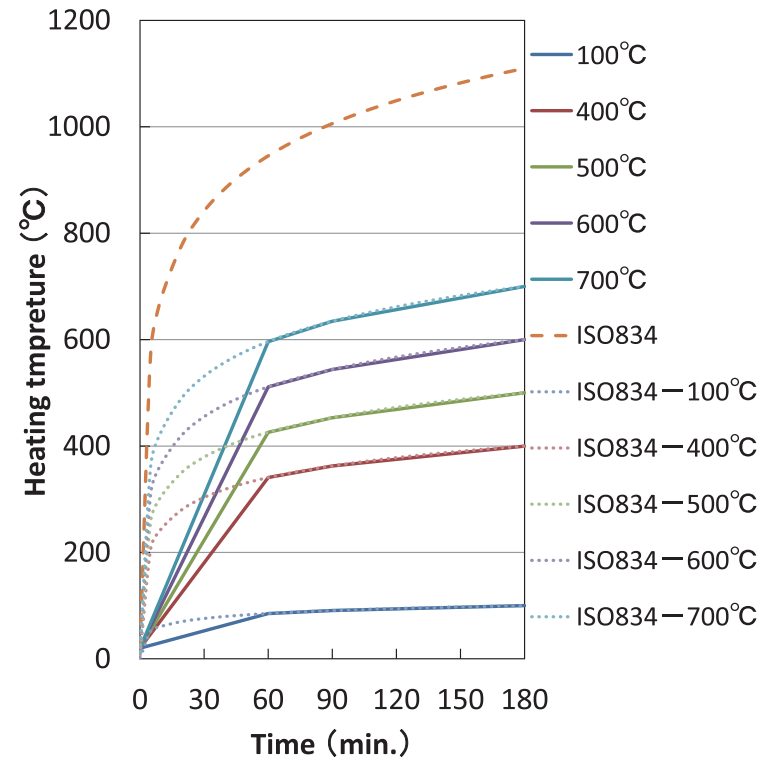

Fig. 2 Heating pattern

酸化というと、コンクリートの劣化原因の一つである中性 化が想像される。中性化が鉄筋位置まで達すると鉄筋の 不動態被膜が破壊され、発錆するデメリットが存在する。

一方で炭酸化コンクリートは寸法安定性に優れ、溶解 度が著しく小さいなどの特性を有し、超長期耐久性の観 点から見直されている ${ }^{9)}$ 。これは炭酸化コンクリートの 主要な相が、炭酸カルシウムであることに起因している。 Fig. 1 に示すように炭酸カルシウムの脱炭酸反応の温度 は 650 900 ${ }^{\circ} \mathrm{C}$ であ。つまりコンクリート構造物の表 面を強制的に炭酸化して主要な相を炭酸カルシウムに変 換することで、火害を受けたコンクリート構造物の供用

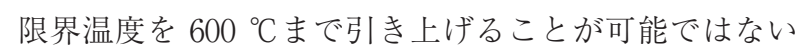
かと考えた。

先に述べたように鉄筋コンクリートの場合、鉄筋位置 まで炭酸化させてしまうと発錆してしまうため、埋設型 枠や耐火パネルへの適用を想定している。本論文では、 強制炭酸化したセメント硬化体の加熱に伴う変化につい て詳細に検討した。

\section{2. 実験}

\section{1 使用材料 - 配合}

Table 1 に使用材料を示す。水結合材比を 50mass\% とし、結合材に OPCのみを使用した場合 (Control 配合) と $\mathrm{OPC}$ と $\gamma-\mathrm{C}_{2} \mathrm{~S}$ を重量比で $1: 1$ として使用した場合 ( $\gamma$ 配合)の 2 水準において試験した。結合材に $\gamma-\mathrm{C}_{2} \mathrm{~S}$
Table 2 Curing conditions

\begin{tabular}{|c|c|c|}
\hline Age & $\lceil$ Seal $\rfloor$ & $\lceil$ Carbonation」 \\
\hline 1day & \multicolumn{2}{|c|}{$\begin{array}{l}\text { After removal from the mold sealing curing } \\
\qquad\left(20^{\circ} \mathrm{C}\right)\end{array}$} \\
\hline 7 day & $\begin{array}{c}\text { Seal } \\
\left(20^{\circ} \mathrm{C}\right)\end{array}$ & $\begin{array}{c}\text { Carbonation } \\
\left(20{ }^{\circ} \mathrm{C}, 60 \mathrm{RH} \%, 20 \mathrm{CO}_{2} \%\right)\end{array}$ \\
\hline 91day & \multicolumn{2}{|r|}{ Experiment } \\
\hline
\end{tabular}

を使用した理由は、 $\gamma-\mathrm{C}_{2} \mathrm{~S}$ は炭酸化反応の活性が高く、 炭酸化反応により空隙構造が緻密化することが知られ ており、本用途に適した材料であると考えたためであ る $^{10-15)}$ 。

\section{2 供試体の作製方法}

供試体は $2 \times 2 \times 8 \mathrm{~cm}$ の角柱供試体とした。練り混ぜ は結合材と水をモルタルミキサ中に投入し、30 秒間低 速で練り混ぜた後、90 秒間高速で練り混ぜた。練り混 ぜたペーストはブリーディングが発生することで、水結 合材比が変化する可能性があるため、ブリーディングが 発生しなくなるまで練り返しを実施した。その後、供試 体を作製した。

\section{3 養生方法}

Table 2 に養生方法を示す。脱型は材齢 1 日とし、材 齢 7 日まで $20{ }^{\circ} \mathrm{C}$ 環境下にて封緘養生を施した。その後、 引き続き封緘養生を施した場合(養生方法：封緘)、供試 体の芯までフェノールフタレイン溶液によって呈色しな い期間 (材齢 91 日)まで促進炭酸化養生を施した場合(養 生方法：炭酸化)の 2 水準の違いを確認することとした。

\section{4 実験内容}

加熱されたペーストの性状を調査するため(1)加熱され る前、(2)加熱された後、(3)加熱された後に $20^{\circ} \mathrm{C}$ 水中養 生を 7 日間施したものの 3 材齢において各種試験を実 施した。(3)を試験水準として選定した理由は、セメント ペースト中に含まれる水酸化カルシウムが分解すると生 石灰となる。また、炭酸化したペーストにおいても炭酸 カルシウムが脱炭酸することで同様に生石灰が生じる。 この生石灰が水和することで体積膨張し、ひび割れが生 じたり、構造体を粗にする可能性がある。これらの影響 も調査するため試験水準として加えた。

加熱温度は $100{ }^{\circ} \mathrm{C} 、 400{ }^{\circ} \mathrm{C} 、 500{ }^{\circ} \mathrm{C} 、 600{ }^{\circ} \mathrm{C} 、 700{ }^{\circ} \mathrm{C}$ とした。Fig. 2 に加熱温度パターンを示す。ISO834に 準拠した標準加熱曲線に(加熱温度／1110)の係数を乗じ た温度パターンとした。ただし、Fig. 2 に示すように急 激な温度上昇までは考慮していない。以上をまとめる と、Table 3 に示す試験水準となる。これらの試験水準 において、X 線回折により相を同定する。熱分析によ り水酸化カルシウム、炭酸カルシウムの定量を実施する。 水銀圧入法により細孔構造を確認する。

(1) X 線回折 (XRD)

$\mathrm{XRD}$ 装置はリガク社製の Multiflex $2 \mathrm{~kW}$ を用いた。 使用した特性 X 線は $\mathrm{CuK} \alpha$ である。管電圧は $20 \mathrm{kV}$ 、 管電流 $2 \mathrm{~mA}$ とし走査速度を $4.0^{\circ}$ \% min. として分析した。 
Table 3 Experiment conditions

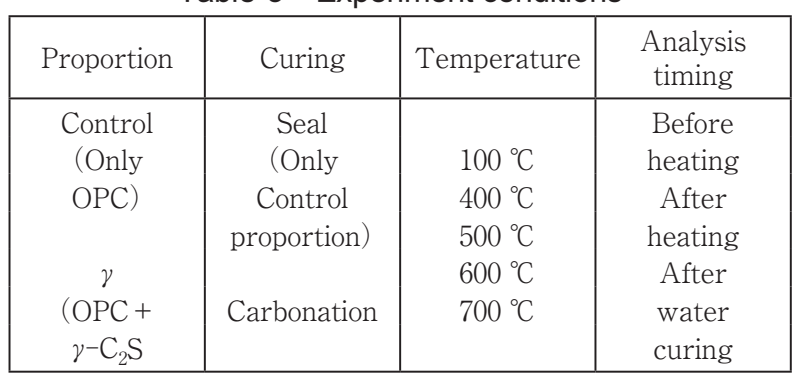

\section{（2）熱分析 (TG-DTA)}

熱分析装置はネッチ・ジャパン社製の TGDTA2000SA を用いた。分析条件は $10^{\circ} \mathrm{C} / \mathrm{min}$. で昇温し、 $1,000{ }^{\circ} \mathrm{C}$ ま゙測定した。

（3）水銀圧入法 $(\mathrm{MIP})$

水銀ポロシメータは島津製作所社製のオートポア IV9520を用いた。測定開始圧力は $0.5 \mathrm{~Pa}$ 、測定最高圧 力は $414 \mathrm{MPa}$ とした。

なお、熱分析と水銀圧入法の試料はハンマーで 2.5 $5 \mathrm{~mm}$ 程度に破砕し 48 時間アセトン浸漬 24 時間以上脱 気乾燥したものを使用した。熱分析については、その後、 微粉砕したものを使用した。

\section{3. 試験結果}

\section{1 加熱前後の分析結果}

(1) XRD

Fig. 3 に各試験水準の X 線回折パターンを示す。加 熱前における供試体の相は、封緘養生においてはセメン 卜鉱物の一つである $\beta-\mathrm{C}_{2} \mathrm{~S}$ やセメント水和物である水 酸化カルシウム $(\mathrm{CH})$ が確認できる。一方、炭酸化養生 においては、カルサイトまたはバテライトといった炭酸 カルシウムが主相である。同図に加熱温度ごとにプロッ トした加熱後の回折パターンを示す。封緘養生では加

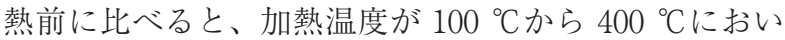
て、CH のピークが小さくなっている。 $500{ }^{\circ} \mathrm{C}$ 以上に加 熱すると $\mathrm{CH}$ のピークが小さくなり、 $\mathrm{CaO}$ のピークが 確認できる。一方、炭酸化養生では加熱前に比べると、 Control、 $\gamma$ 配合のいずれにおいても、加熱温度が大き くなるにつれ炭酸カルシウムに起因するピークは相対的 に小さくなるものの回折パターンはほぼ同様である。こ れらの結果からセメント硬化体を炭酸化することにより 炭酸カルシウムが形成され、セメント水和物よりもより 加熱に強い形態となっていることがわかる。

(2) TG-DTA

Fig. 4 に水酸化カルシウム量の定量結果を、Fig. 5 に 炭酸カルシウム量の定量結果を示す。定量結果は強熱減 量を測定し、初期結合材料に対する定量結果とした。水 酸化カルシウムの含有量は、封緘養生において焼成温度

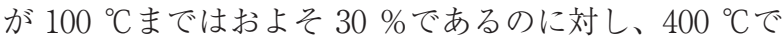

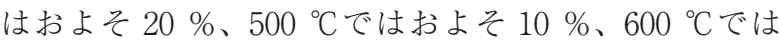
およそ $5 \%$ まで小さくなっている。これらの結果から

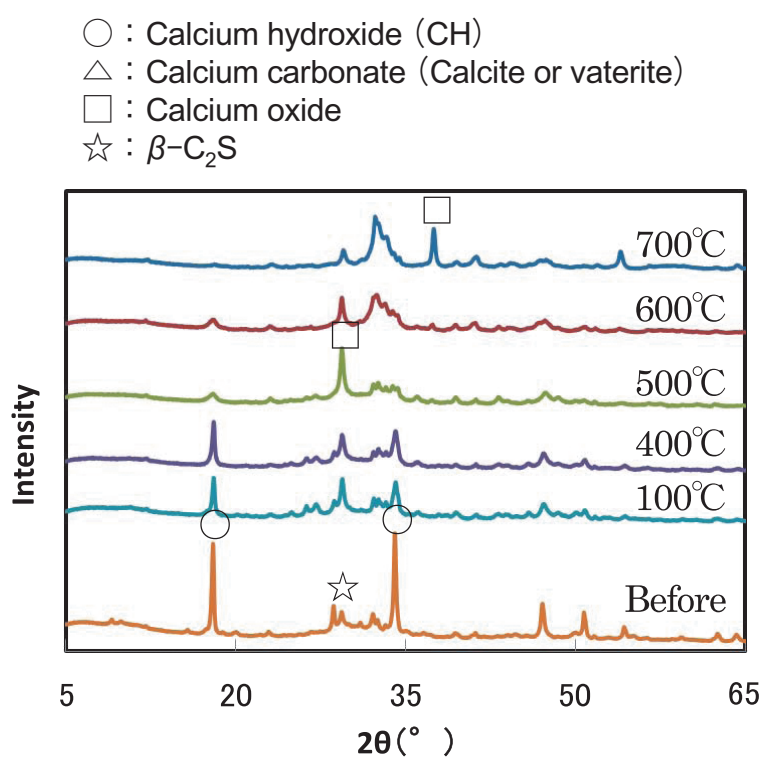

(a) Control-Seal

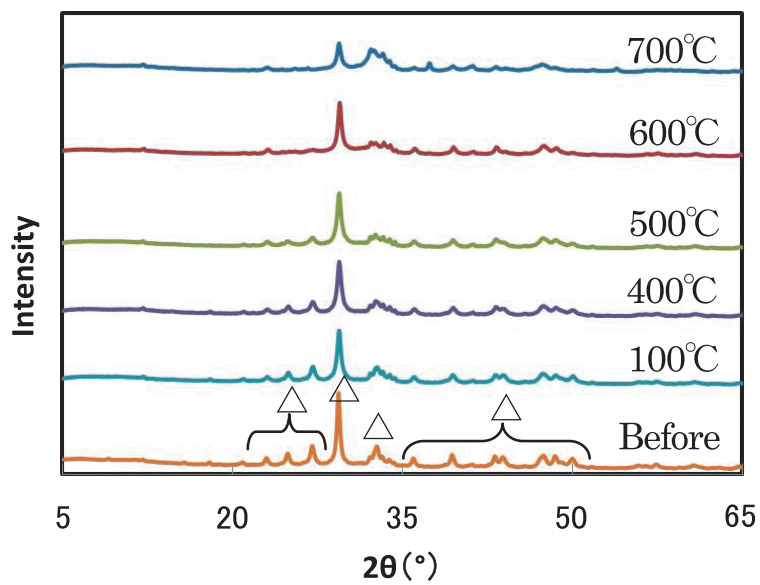

(b) Control-Carbonation

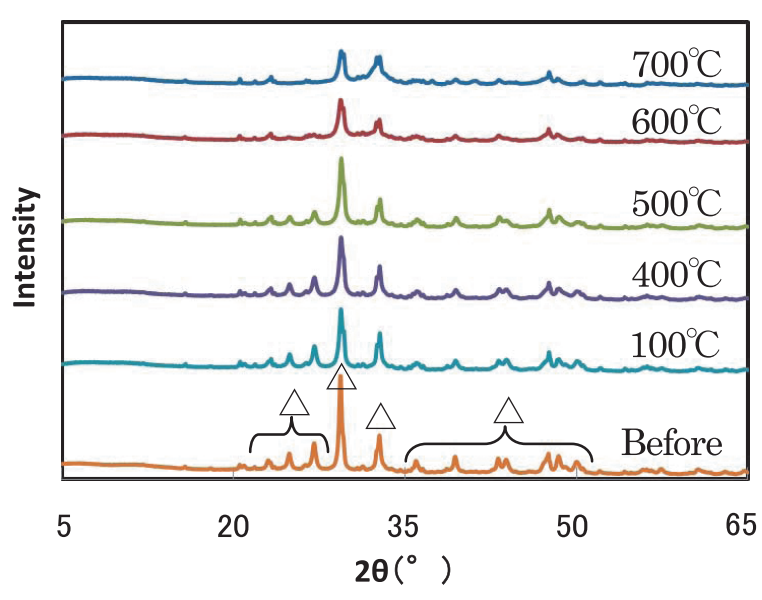

(c) $\gamma$-Carbonation

Fig. 3 XRD pattern

水酸化カルシウムは、加熱温度が $400{ }^{\circ} \mathrm{C}$ 程度から分解 していることが示唆される。この值は一般的に知られて いる水酸化カルシウムの分解温度と同じである。炭酸力 ルシウムの含有量は Control 配合の封緘養生ではほとん 


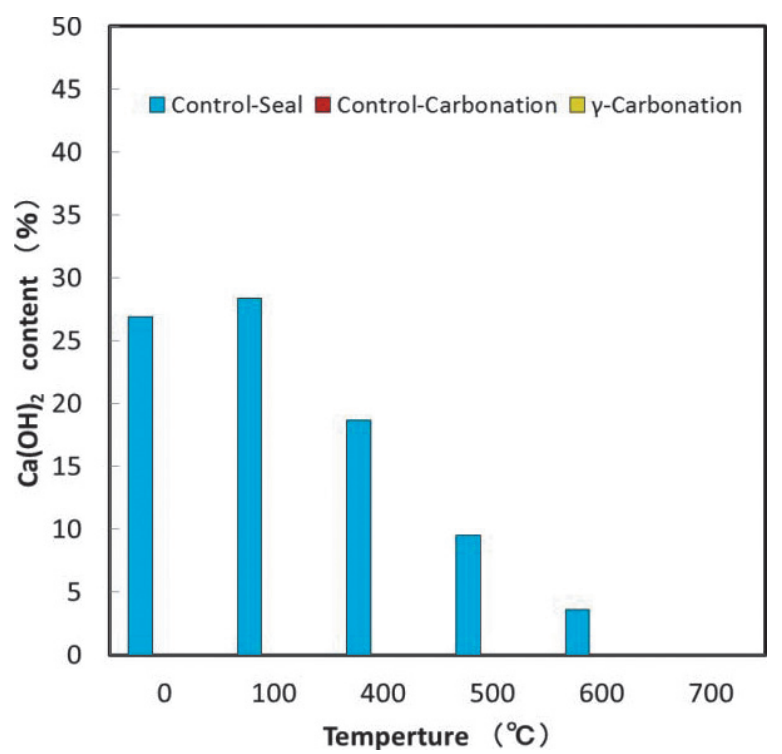

Fig. 4 Determination of calcium hydroxide

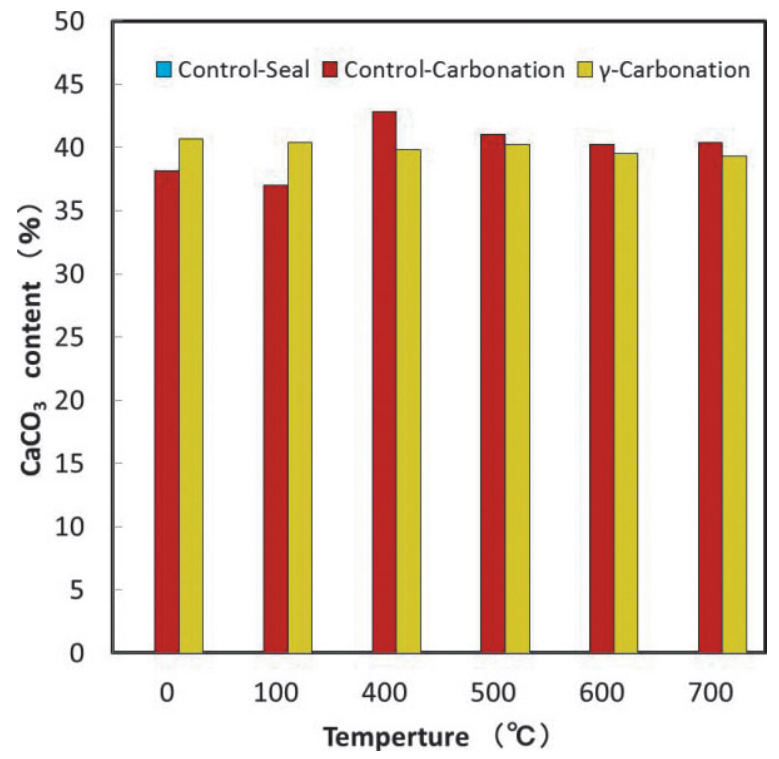

Fig. 5 Determination of calcium carbonate

ど確認できない。Control 配合、 $\gamma$ 配合ともに炭酸化養 生では加熱温度によらず、およそ $40 \%$ 程度の含有量で あった。このことから加熱温度が $700{ }^{\circ} \mathrm{C} て ゙$ 短時間の加 熱であれば、炭酸カルシウムの脱炭酸の量はわずかであ ることが予想される。

Control 配合の炭酸化養生では加熱温度が $400{ }^{\circ} \mathrm{Cにお}$ いて炭酸カルシウム量が大きい。理由は定かではない が、C-S-H が加熱中に炭酸化されたと予想される。

(3) MIP

Fig. 6 に加熱前後の空隙径分布を示す。封緘養生の条 件下では $400{ }^{\circ} \mathrm{C}$ 以上に加熱した場合、 $0.1 \mu \mathrm{m}$ 付近の空 隙量が増加している。炭酸化養生の条件下においては、 $600{ }^{\circ} \mathrm{C}$ の加熱までは空隙構造は変わらず、700 ${ }^{\circ} \mathrm{C}$ に加熱 した場合、 $0.01 \mu \mathrm{m}$ 付近の空隙量が増加している。加熱

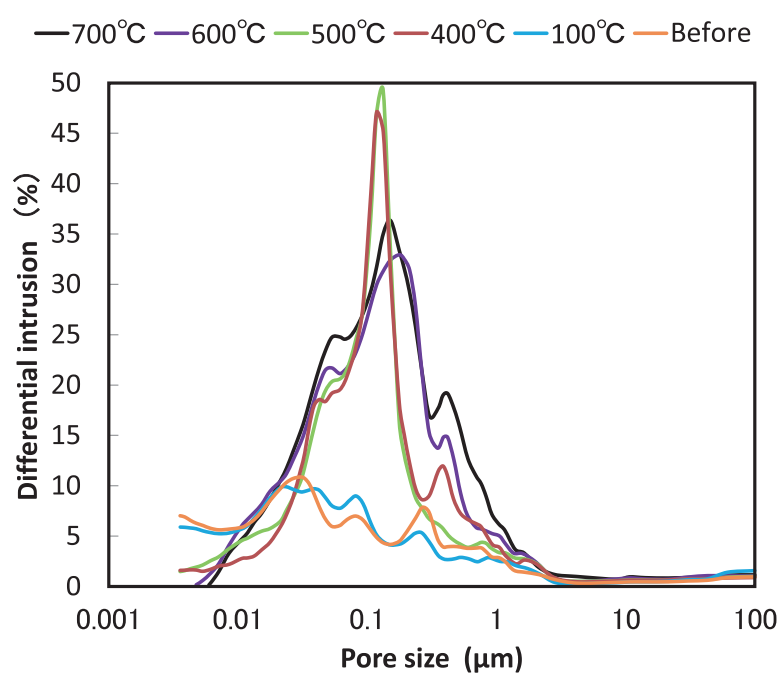

(a) Control-Seal

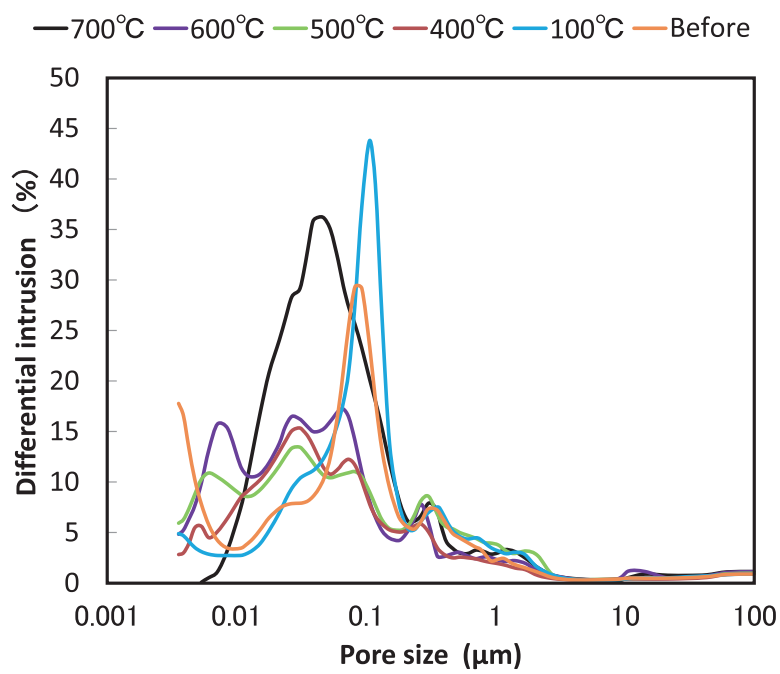

(b) Control-Carbonation

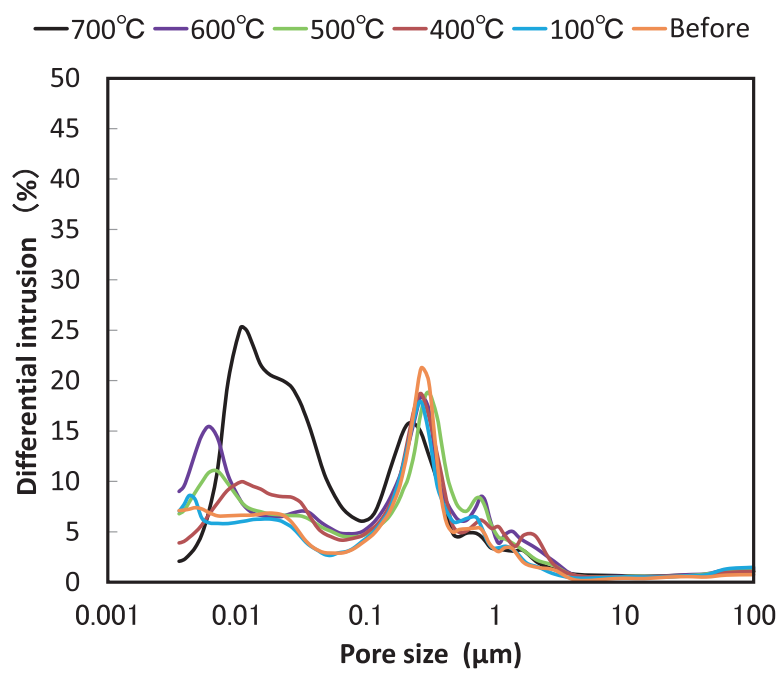

(c) $\gamma$-Carbonation

Fig. 6 MIP

によって封緘養生の方が炭酸化養生に比べ、粗大な空隙 が生成されていることが分かる。つまり火害にあったと 
しても、水酸化カルシウムの分解よりも炭酸カルシウム が脱炭酸した方がより細かい空隙となり、強度低下も小 さい可能性がある。

Table 4 に空隙量を示す。配合の違いを確認すると、 $\gamma$ 配合は Control 配合に比べ空隙量が少ない。このこと から $\gamma-\mathrm{C}_{2} \mathrm{~S}$ を使用することで、より強度低下の小さい 部材となる可能性がある。

\section{2 加熱後水中養生を施した供試体の外見}

Fig. 7 と Fig. 8 に加熱後の供試体と加熱後水中養生 を施した供試体の写真を示す。炭酸化養生の供試体につ

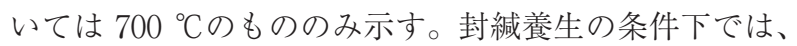
封緘養生において水中養生前後の相組成を比較するた め、XRDによる相同定を実施した。Fig. 9 より水中養 生後加熱温度が $400{ }^{\circ} \mathrm{C}$ 以上において、ひび割れが確認 できる。

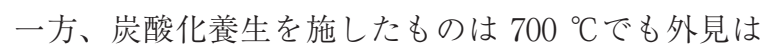
健全である。水中養生を施すと封縅養生の供試体ではひ び割れ幅が大きくなっている。炭酸化養生の供試体は加

\begin{tabular}{|c|c|}
\hline Temperature & After heating \\
\hline $100{ }^{\circ} \mathrm{C}$ & \\
\hline $400{ }^{\circ} \mathrm{C}$ & \\
\hline $600{ }^{\circ} \mathrm{C}$ & \\
\hline $700{ }^{\circ} \mathrm{C}$ & \\
\hline
\end{tabular}

(a) Control-Seal

\begin{tabular}{|c|c|}
\hline Temperature & After heating \\
\hline $700{ }^{\circ} \mathrm{C}$ & \\
\hline
\end{tabular}

(b) Control-Carbonation

\begin{tabular}{|c|c|}
\hline Temperature & After heating \\
\hline $700{ }^{\circ} \mathrm{C}$ & \\
\hline
\end{tabular}

(c) $\gamma$-Carbonation

Fig. 7 After heating
熱前後との違いは確認できなかった。Fig. 3(a)と Fig. 9 を比較考察すると、加熱によって生成した生石灰が再度

Table 4 Amount of Pore

\begin{tabular}{|c|c|c|c|}
\hline Proportion & Curing & Temperature & $\begin{array}{c}\text { Pore Volume } \\
(\%)\end{array}$ \\
\hline \multirow{8}{*}{ Control } & \multirow{4}{*}{ Seal } & 100 & 26.1 \\
\hline & & 400 & 31.6 \\
\hline & & 600 & 37.4 \\
\hline & & 700 & 40.9 \\
\hline & \multirow{8}{*}{ Carbonation } & 100 & 16.6 \\
\hline & & 400 & 19.4 \\
\hline & & 600 & 25.3 \\
\hline & & 700 & 35.3 \\
\hline \multirow{4}{*}{$\gamma$} & & 100 & 18.3 \\
\hline & & 400 & 22.1 \\
\hline & & 600 & 24.3 \\
\hline & & 700 & 31.1 \\
\hline
\end{tabular}

\begin{tabular}{|c|c|}
\hline Temperature & After water curing \\
\hline $100{ }^{\circ} \mathrm{C}$ & \\
\hline $400{ }^{\circ} \mathrm{C}$ & \\
\hline $600{ }^{\circ} \mathrm{C}$ & \\
\hline $700{ }^{\circ} \mathrm{C}$ & \\
\hline
\end{tabular}

(a) Control-Seal

\begin{tabular}{|c|c|}
\hline Temperature & After water curing \\
\hline $700{ }^{\circ} \mathrm{C}$ & \\
\hline
\end{tabular}

(b) Control-Carbonation

\begin{tabular}{|c|c|}
\hline Temperature & After water curing \\
\hline $700{ }^{\circ} \mathrm{C}$ & \\
\hline
\end{tabular}

(c) $\gamma$-Carbonation

Fig. 8 After water curing 


\section{$\bigcirc$ : Calcium hydroxide}

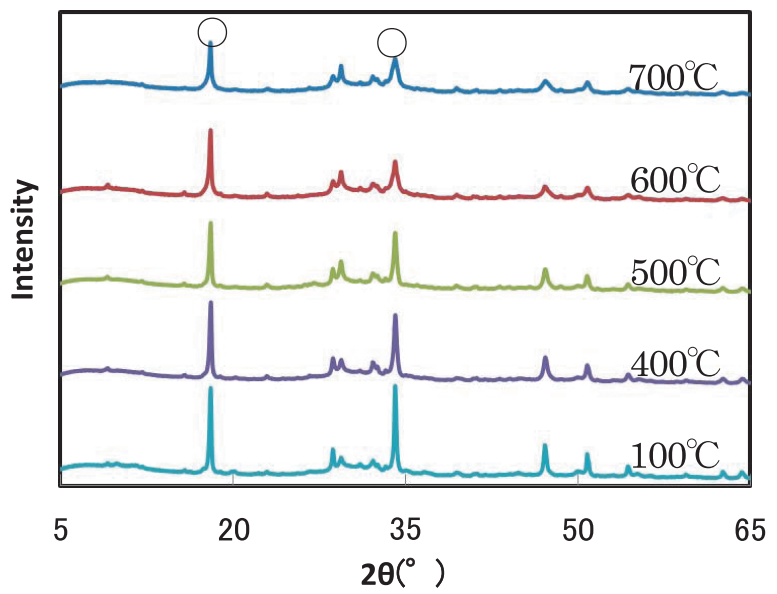

Fig. 9 XRD pattern of Seal - After water curing

消石灰に変化していることがわかる。これらのことから 封緘養生では加熱に伴い、空隙量の増加、生石灰の生成 が進行し、水中養生を施すことでさらに膨張し、ひび割 れ幅が大きくなったものと考える。炭酸化養生では、い ずれの加熱温度においても生石灰は生成されておらず、 ひび割れに至るまでの組成変化、膨張・収縮は生じなかっ たものと予想される。

\section{4. まとめ}

強制的に炭酸化したセメントペーストの各種分析を実 施し、下記の知見を得た。

（1）封緘養生を施したセメントペーストは 400 500 ${ }^{\circ} \mathrm{C}$ で水酸化カルシウムが脱水する。また、脱水に伴い、 $400{ }^{\circ} \mathrm{C}$ 以上の加熱を受けると直径 $0.1 \mu \mathrm{m}$ 程度の空 隙が増加する。

（2）炭酸化養生を施したセメントペーストは $600{ }^{\circ} \mathrm{C}$ までの加熱であれば相組成は変化しない。また、 $600{ }^{\circ} \mathrm{C}$ 以上の加熱を受けると、脱炭酸に伴い直径 $0.01 \mu \mathrm{m}$ 程度の空隙が増加する。これは封緘養生に 比べると一桁小さく、強度低下への影響も小さいも のと推測される。

（3） $\gamma-\mathrm{C}_{2} \mathrm{~S}$ を添加し、炭酸化養生を施すと加熱後の総空 隙量が小さい。

以上のことからセメントペーストを強制的に炭酸化す ることで、耐火性能を向上できる可能性があることを明 らかにした。また、炭酸化反応活性の高い $\gamma-\mathrm{C}_{2} \mathrm{~S}$ を使 用することでより強度低下の小さい部材が製造できる可 能性を示した。

\section{謝辞：}

本論文を執筆するにあたり古賀吏典氏に多大なるご協 力をいただきました。ここに感謝の意を表します。

\section{参考文献：}

1）山田幹郎、堀口敬、佐伯昇：高強度コンクリートの
耐火性能に関する基礎的実験、コンクリート工学、 Vol. 53 ${ }^{\text {rd }}$, pp. 236-237 (1999)

2) PENG G F, et al. : Chemical kinetics of $\mathrm{C}-\mathrm{S}-\mathrm{H}$ decomposition in hardened cement paste subjected to elevated temperatures up to $800{ }^{\circ} \mathrm{C}$, Adv Cem Res, Vol. 13, No. 2, pp. 47-52 (2001)

3) PHAN L T, CARINO N J : Effects of Test Conditions and Mixture Proportions on Behavior of High-Strength Concrete Exposed to High Temperatures, ACI Mater J, Vol. 99, No. 1, pp. 54-66 (2002)

4) POON C-S, AZHAR S : Deterioration and Recovery of Metakaolin Blended Concrete Subjected to High Temperature, Fire Technol, Vol. 39, No. 1, pp. 35-45 (2003)

5) UYSAL Mucteba, et al. : Properties and behavior of self-compacting concrete produced with GBFS and FA additives subjected to high temperatures, Constr Build Mater, Vol. 28, No. 1, pp. 321-326 (2012)

6) AYDIN Serdar, BARADAN Buelent: High Temperature Resistance of Alkali-Activated Slagand Portland Cement-Based Reactive Powder Concrete, ACI Mater J, Vol. 109, No. 4, pp. 463-470 (2012)

7）独立行政法人建築研究所：構造部材の耐火性能、 Epistula、Vol. 47 (2009)

8）日本建築学会：建築工事標準仕様書 · 同解説 JASS5 鉄筋コンクリート工事 2015 (2015)

9）横関康祐、盛岡実、伊藤裕二：長寿命コンクリー 卜「EIEN」による構造物の高耐久化、電力土木、 No. 342、pp. 60-62 (2009)

10）盛岡実、樋口隆行 : $\gamma-2 \mathrm{CaO} \cdot \mathrm{SiO}_{2}$ の中性化抑制効 果とその機構、セメント・コンクリート論文集、 No. 57、pp. 23-29 (2003)

11）芦澤良一ほか：セメント系材料の高耐久化を目的と した養生方法に関する研究、コンクリート工学年次 論文集、Vol. 26、No. 1、pp. 747-752（2004）

12）芦澤良一ほか： $\gamma-2 \mathrm{CaO} \cdot \mathrm{SiO}_{2}$ と炭酸化養生を併用し たコンクリートの高耐久化、鹿島技術研究所年報、 Vol. 52、pp. 107-112 (2004)

13）盛岡実ほか：セメント硬化体の中性化に及ぼす $\gamma-2 \mathrm{CaO} \cdot \mathrm{SiO}_{2}$ 置換率の影響、セメント・コンクリー 卜論文集、No. 58、pp. 282-288（2004）

14）小薮将人ほか：炭酸化反応を用いたモルタルのち密 化に関する材料および養生方法の影響、土木学会 年次学術講演会講演概要集、Vol. $60^{\text {th }}$ 、No. Disk 2、 No. 5-207 (2005)

15）取違剛ほか：コンクリートの炭酸化による耐摩耗性 向上に関する研究、コンクリート工学年次論文集、 Vol. 30、No. 1、pp. 573-578（2008） 


\title{
CHANGES ASSOCIATED WITH THE HEATING OF THE CARBONATION CEMENT PASTE
}

\author{
Makoto SHOJI¹ ${ }^{*}$, Minoru MORIOKA ${ }^{* 2}$, Kosuke YOKOZEKI³ ${ }^{* 3}$ and Keiichi IMAMOTO*4
}

*1 DENKA Co. Ltd., Infrastructure \& Social Solutions, Special Cement Additives Dept. (Nihonbashi Mitsui Tower, 2-1-1, Nihonbashi-Muromachi, Chuo-ku, Tokyo 103-8338, Japan)

*2 DENKA Co. Ltd., Omi Plant, Cement and Special Cement Additives Reserch Laboratory（2209, Omi, Itoigawa-shi, Niigata 949-0393, Japan)

*3 KAJIMA Co. Ltd., Technical Research Institute (2-19-1, Tobitakyu, Chofu-shi, Tokyo 1820036, Japan)

*4 TOKYO UNIVERSITY OF SCIENCE, Faculty of Engineering Division II, Department of Architecture (6-3-1, Niijuku, Katsushika-ku, Tokyo 125-8585, Japan)

\begin{abstract}
The cement paste carbonated, was studied change with heating. Sealing curing cement paste, the decomposition of calcium hydroxide and heated to more than $400{ }^{\circ} \mathrm{C}$, the pore of about $0.1 \mu \mathrm{m}$ was increased. On the other hand, no significant change was observed in were subjected to carbonation curing cement paste changes and void structure of even phase composition was heated up to $600{ }^{\circ} \mathrm{C}$. When heated to $700{ }^{\circ} \mathrm{C}$, the pore of about $0.01 \mu \mathrm{m}$ was increased. Further, when the active poor carbonation in hydraulic was used as part of a high gamma- $\mathrm{C}_{2} \mathrm{~S}$ the binder, void volume after heating was reduced.
\end{abstract}

KEY WORDS : Refractory, Carbonation, Calcium hydroxide, Calcium carbonate, Cement paste 